О. Л. Білка

\title{
ЯВИЩЕ ПОЛІСЕМІЇ ТА ЛЕКСИЧНОЇ ОМОНІМЇ̈ В БІОЛОГІЧНІЙ ТЕРМІНОЛОГІЇ УКРАЇНСЬКОЇ МОВИ
}

Білка О. Л. Явище полісемії та лексичної омонімії в біологічній термінології української мови.

У статті розкрито критерії розмежування полісемії та лексичної омонімії в біологічній термінології. Доведено, що багатозначність розвивають здебільшого однослівні терміни вторинної номінації, які мають щонайбільше два значення. Омонімія біологічних термінів зумовлена втратою семантичних зв'язків між лексикосемантичними варіантами полісемічного слова.

Ключові слова: омонімія, полісемія, сема, семантичний аналіз.

Белка Е. Л. Явление полисемии и лексической омонимии в биологической терминологии украинского языка.

В статье раскрыто критерии разграничения полисемии и лексической омонимии в биологической терминологии. Доказано, что многозначность развивают однословные термины вторичной номинации, которые имеют более двух значений. Омонимия биологических терминов обусловлена потерей семантических связей между лексикосемантическими вариантами полисемического слова.

Ключевые слова: омонимия, полисемия, сема, семантический анализ.

Bilka O. L. Phenomenon polysemyy and leksycheskoy omonymyy byolohycheskoy terminology in Ukrainian language.

In Article solved Criteria razhranychenyya polysemyy and leksycheskoy omonymyy in byolohycheskoy terminology. Proved, that mnohoznachnost razvyvayut odnoslovnыe of 
Terms vtorychnoy nomynatsyy, kotorbe ymeyut more than two values. Omonymyya Biology termynov obuslovleno rubbed semantycheskyh bonds Between lexical variants semantycheskymy polysemycheskoho words.

Key words: omonymyya, polysemyya, Sam semantycheskyy analysis.

Питання про розмежування лексичної омонімії та полісемії є досить складною проблемою. Одні мовознавці визнавали існування омонімії, натомість, заперечували полісемію. Так, О. Потебня свого часу наголошував, «де два значення, там два слова» [5, с. 33]. Тієї самої думки дотримувався й Л. Щерба: «Неправильно думати, що слова мають кілька значень. Насправді ми маємо стільки слів, скільки дане фонетичне слово має значень» $[10$, с. 78]. Цей погляд не сприймають сучасні мовознавці. Ю. Степанов, спираючись на вчення О. Потебні про найближчі і найдальші значення слів, уважає, що «в кожну епоху слово функціонує в загальній мові у своєму найближчому значенні і водночас у різних спеціальних сферах спілкування, головним чином у мові науки, а також у різних професійних колективах - у своїх найдальших значеннях. Найдальші значення, розвиваючись на основі найближчих значень, зрештою досягають такої відмінності від найближчих, що перетворюються в спеціальні терміниомоніми до вихідного» [9, с. 16].

Зовні явище полісемії подібне до лексичної омонімії, але це лише зовнішнє враження. Дослідники переконують, що двоє i більше номінативних значень можуть об'єднуватися в одному слові лише в тому разі, якщо одне або двоє 3 них є похідними від основного. Якщо ж такого зв'язку між значеннями немає, то ми маємо справу вже з двома омонімами [9, с. 13]. Г. Мукан зазначила, щоб визначити межу між полісемією та омонімією, треба розглядати зовнішні й внутрішні ознаки в нерозривній єдності, брати до уваги наявність чи відсутність внутрішнього значеннєвого зв'язку між семантикою співзвучних слів, і лише при втраті мотивування спільної ознаки в семантичній структурі слів уважати їх омонімами [4, с. 35].

На принципову відмінність між значеннями полісемічного і омонімічного слова звертає увагу О. Ахманова. Полісемія, на їі думку, це тотожність слова за наявності в нього двох або більшої кількості виразно відмінних значень, які мають зв'язок з прямим номінативним значенням, а омонімія - це зовнішній збіг за звуковою оболонкою двох i більше слів [2, с. 104]. В. Абаєв, розмежувавши полісемію і омонімію, схематично зобразив багатозначність як дві лінії, що виходять 3 однієї точки, тобто вказав на значеннєву залежність двох значень (схема 1), а лексичну омонімію, як дві паралельні лінії, що вказує на відсутність семантичних зв’язків між словами в сучасній мові (схема 2) [1, с. 33].

Відношення полісемї

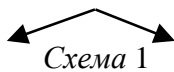

Відношення омонімії

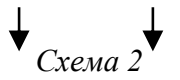


Серед критеріїв розмежування лексичної омонімії та полісемії, наявних у наукових дослідженнях, найприйнятнішим $\epsilon$ : семантичний аналіз лексичних значень слів, що мають однаковий план вираження; виявлення типу зв'язку між семами (повторюваних, тобто регулярних, або нерегулярних); з'ясування дериваційних зв'язків мовних одиниць; порівняння їхніх граматичних значень; установлення належності однозвучних слів до різних тематичних груп тощо [6, с. 129]. Оскільки перехід багатозначності в лексичну омонімію є живим процесом, то між цими явищами немає і не може бути абсолютної межі. «Разом із безсумнівними лексичними омонімами, - резюмує О. Романова, - спостерігаємо проміжні випадки, особливо тоді, коли лексична омонімія утворюється внаслідок розщеплення структури терміна-полісеманта» [7, с. 129]. Дослідниця порушує актуальне питання про необгрунтоване та невиправдане об'єднання у словникарських працях значень, що не мають спільної семи, в одній семантичній структурі. Як приклад подаємо лексикографічне опрацювання мовної одиниці глухар у Великому тлумачному словнику сучасної української мови [ВТССУМ]: глухар - «1. Великий птах з родини тетеревових. 2. Глуха людина. 3. Великий гвинт із иестигранною або квадратною голівкою» [3, с. 246]. Перші два значення мають спільну сему «Глухий», а третє вважаємо омонімічним до кожного з них. На наш погляд, слід подавати значення слова глухар як омонімічне: глухар1 (перше та друге значення) - әлухар2 (третє значення).

У ВТССУМ безпідставно кодифіковано як лексичні омоніми й деякі інші одиниці. Напр.: щцитник1 - «ремісник, який виготовляе щитии; ццитник - «багаторічна рослина з довгими (до 100 см) пірчастими листками, покривальце спорангія якої схоже на щзит» [3, с. 1639]. 3 огляду на те, що ці значення мають спільну сему «щит» (ремісник виготовляє щит і покривальце спорангія у папоротей має щитоподібну форму), пропонуємо вважати їх полісемантами: щитник1 (перше і друге значення). Яzідник1 «1. Кущова рослина, яка дає їстівні плоди - ягоди. 2. Той, хто вирощує ягідні культури або збирає ягоди». Ягідник2 - «місие, де ростуть ягоди» [3, с. 1645]. Усі три значення мають спільну сему «ягода», тому їх слід подавати в одній словниковій статті: ясідник (перше, друге і третє значення). Туніка1 - «1. Одяг стародавніх римлян, вид сорочки з короткими рукавами чи без рукавів. 2. Одяг у вигляді мішка з отворами для голови і ніг, який зазвичай покриває все тіло. Туніка2 - «1. зоол. Складка шкіри у деяких безхребетних тварин, щчо оперізує тіло. 2. бот. Зовнішній шар конусоподібної верхівки рослин» [3, с. 1485]. Усі чотири значення цього слова мають спільну сему «покривати що-небудь», тому пропонуємо вважати їх полісемантами: туніка (перше, друге, третє і четверте значення).

Явище лексичної омонімії досить часто ототожнюють із виявом багатозначності. У полісемічних словах наявні два і більше різних () О. л. Білка, 2013. 
значення, які, на відміну від омонімів, мають зв'язок із первинним словом. «Якщо полісемія упорядковує терміни всередині терміносистеми біологічних наук, тобто формує іiі ядро, - зазначає Л. Симоненко, - то лексична омонімія належить до тих процесів, які упорядковують номінативні одиниці біологічної терміносистеми і цим зв'язують іiі 3 іншими науковими системами» [8, с. 46]. Основним критерієм розмежування лексичної омонімії та полісемії має бути саме семантичний аналіз лексичних значень слів, за яким установлюємо наявність чи відсутність значеннєвого зв'язку між семами цих одиниць.

\section{Література}

1. Абаев В. И. О подаче омонимов в словаре / В. И. Абаев // Вопросы языкознания. 1957. - № 3. - C. 31-43.

2. Ахманова О.С. Очерки по общей и русской лексикологии : [Текст] / О. С. Ахманова. - М. : Просвещение, 1957. - 362 с.

3. Великий тлумачний словник сучасної української мови (з дод. і допов. та СД) / [уклад. і голов. ред. В. Т. Бусел]. - К. : Ірпінь : ВТФ «Перун», 2009. - 1736 с.

4. Мукан Г. М. Багатозначність і омонімія / Г. М. Мукан // Українська мова i література в школі. - 1970. - № 8. - С. 30-36.

5. Потебня А. А. Из записок по русской грамматике : [Текст] / А. А. Потебня. М. : Учпедгиз, 1958. - 536 с.

6. Родзевич Н. С. Про будову складних слів у сучасній українській мові / Н. С. Родзевич // Українська мова в школі. - 1952. - № 6. - С. 10-19.

7. Романова О. О. Українська термінологія швацької промисловості: дисертація на здобуття наук. ступеня канд. філол. наук : спец. 10.02.01 «Українська мова» / Оксана Олександрівна Романова. - Харків, 2009. - 201 с.

8. Симоненко Л. О. Біологічна термінологія: формування та функціонування : [навч. посіб.] / Л. О. Симоненко. - Умань : РВЦ «Софія», 2006. - 104 с.

9. Степанов Ю. С. Основы общего языкознания : [учеб. пособ.] / Ю. С. Степанов. М. : Просвещение, 1975. - 271 с.

10. Щерба Л. В. Опыт общей теории лексикографии / Л. В. Щерба // Избранные труды по языкознанию и фонетике. Т. 1 - Л. : ЛГУ, 1985. - С. 54-91. 